\title{
Türkiye'de Sendikal Örgütlenme ve Eşitsizlik
}

\author{
Doç. Dr. Ramazan TIYYEK \\ Kırklareli Üniversitesi, İktisadi ve İdari Bilimler Fakültesi, \\ Çalışma Ekonomisi ve Endüstri İlişkileri \\ ramazan.tiyek@klu.edu.tr, Orcid ID: 0000-0002-3442-3517
}

\section{$\ddot{\mathbf{O z}}$}

Bu çalışmada, Türkiye'de sendikal örgütlenme düzeylerindeki farklılıklar ile sendikal hakların kullanımındaki eşitsizlikler değerlendirilmiştir. Piyasanın işleyişinde yer verilmek istenmeyen sendikaların örgütlenme düzeyleri, İskandinav Bölgesi haricinde, çalışanları temsil gücünden yoksun bırakabilecek şekilde aşağı seviyelerdedir. Emeğin örgütlenmesinde Dünya genelindeki eşitsizlik hali Türkiye'de de benzer bir durum göstermekte olup çalışanların sadece \% 13'ü sendikalara üyedir. Bazı işkollarında \% 1 'in altında olan örgütlenme oranları, toplu iş sözleşmesinden yararlanma düzeyi açısından değerlendirildiğinde çok daha aşağı seviyelerdedir. Bir diğer eşitsizlik ise sendikal hakların kullanımındadır. Çalışanlar için toplu pazarlık sürecinde işverenlere karşı önemli bir caydırıcı güç olan grevler 'genel sağlık veya milli güvenliği bozucu nitelikte olması' gerekçesiyle geçici olarak ertelenebilmektedir. Geçici olan sürenin sona ermesinde taraflar arasındaki anlaşmazlığın devam etmesi durumunda ise tekrar grev sürecinin başlaması yerine Yüksek Hakem Kurulu'nun vereceği karar bağlayıcı olmaktadir.

Anahtar Kelimeler: Sendikal Örgütlenme, Eşitsizlik, Toplu Pazarlık, Toplu İş Sözleşmesi, Grev

JEL Sinıflandırması: J51, J52, J53 


\title{
Union Organization and Inequality
}

\begin{abstract}
Differences and inequalities in the use of trade union rights in Turkey unionisation levels were evaluated in this study. The level of organization of unions, which are preferred to be excluded in the functioning of the market, is at a low level, except for the Scandinavian Region, which may deprive workers of their representative power. The organization of labor shows a similar situation in Turkey in terms of inequality throughout the world only $13 \%$ of employees are members of unions. The organizational rates, which are below $1 \%$ in some lines of business, are much lower when evaluated in terms of the level of benefiting from the collective agreement. Another inequality is in the use of trade union rights. Strikes, which are an important deterrent to employers in the process of collective bargaining for employees, can be postponed temporarily on the grounds of "disrupting general health or national security". In case of disagreement between the parties at the end of the temporary period, the decision of the Supreme Arbitration Board will be binding instead of the start of the strike process again.
\end{abstract}

Keywords: Union Organization, Inequality, Collective Bargaining, Collective Bargaining Agreement, Strike.

JEL Classification: J51, J52, J53

\section{Giriş}

Sendikal örgütlenme, ilk olarak Sanayi Devrimi ile birlikte işçi sınıfının ortaya çıkmaya başladığı İngiltere'de 1792 yılında oluşturulmuştur. Sadece belirli vasıflardaki kişilerin sendika üyesi olabildikleri ilk sendikalaşma tecrübeleri başarısızlıkla sonuçlanmış ve sendikalar 1824 yılına kadar yasaklanmıştır. Sonraları ise İngiltere ile birlikte ABD, Almanya ve Fransa gibi sanayileşmeye başlayan ülkelerde sendikalara özgürlükler verilmiş, çalışanlar sendikaları aracılığı ile çalışma hayatında endüstri ilişkilerinin önemli bir aktörü olarak yer almaya başlamıştır. Chartizm Hareketi (18381848) sonrasında elde edilen genel oy hakkı, çalışanların bir vatandaş olarak görülmeye başlanması, sendikal mücadelenin başarıya ulaşmasında önemli bir dönüm noktasıdır (Uslu, 2014: 1-24). Büyük Buhran (1929) gibi önemli ekonomik krizlerin olduğu dönemlerde hem emek hem de emek mücadelesi durgunlaşma dönemine girerken sonrasındaki müdahaleci yaklaşımlarla birlikte özellikle II. Dünya Savaşı'ndan sonra sendikal örgütler altın çağını yaşamışlardır. 1980'li yıllarla birlikte ise bir sebebi de ekonomideki neoliberal politikalarla sendikalaşma zayıflamaya başlamıştır. 
Sendikal örgütlenmenin büyüyüp gelişmesinde sınıf bilinci önemli bir aşamadır. Sanayileşmenin Osmanlı Devleti'nde Batı'daki ülkelerden çok geç yaşanmış olması sendikalaşmanın da Türkiye'de geç oluşmasına ve bununla birlikte sınıf bilincinin gecikmesine neden olmuştur. 1870'li yıllarla birlikte çalışanlar arasındaki yardımlaşma dernekleri ilk sendikalar olarak değerlendirilmektedir. 1909 yılında Tatil-i Eşgal Kanunu ile getirilen düzenlemeler sendikal örgütlenmeyi olumsuz etkilemiş, 1938 yılındaki Ceza Yasası ile de sendikalaşma tamamen yasaklanmıştır. 1932 yılında üye olunan Uluslararası Çalışma Örgütü (ILO)'nun etkileri ve demokratikleşme çalışmalarının meyvesi olarak 1946 yılında sendikal örgütlenmenin önündeki yasaklar kaldırılmış, 1947 yılında da sendikalaşmayı düzenleyen ilk yasal düzenleme yürürlüğe girmiştir. 1961 Anayasa'sında 'sosyal devlet' ilkesine yer verilmesi ile birlikte 1963 yılında ilk defa grev 'hak' olarak tanımlanmıştır. 1961 Anayasası ile getirilen haklardan, önce 1971 yılında memurların sendikalaşması engellenmiş, 1983 yılında çıkarılan Toplu İş Sözleşmesi, Grev ve Lokavt Kanunu ile birlikte 'hak grevi' yapılması yasaklanmış, sadece 'çıkar grevi' yasal bir grev olarak benimseniştir.

OECD ülkeleri içerisindeki sendikalaşma oranlarına bakıldığında Türkiye'nin çok iyi durumda olmadığı söylenebilir. Yürürlükte olan 6356 sayılı kanuna göre 20 işkolunun belirlendiği Türkiye'de işkolları arasında sendikalaşma oranlarının çoğu işkolunda ortalamanın altında bir düzeyde hatta bazı işkollarında \% 1'lerin altında olup işkolları arasında ciddi bir eşitsizlik söz konusudur. Kayıt dışı çalışanların sendikalaşma oranlarının hesaplanmasında dikkate alınmaması da Türkiye'deki sendikal örgütlenmenin yorumlanması açısından önemli bir parametredir. Toplu pazarlık yapma sürecinde her sendikanın yetkili olmayabileceği düşünüldüğünde veya toplu pazarlıklar neticesinde imzalanan toplu iş sözleşmesinden yararlananlar sendikalaşma oranının hesabında dikkate alındığında örgütlenme düzeyinin resmi olarak açıklanan oranlarda olmadığı anlaşılmaktadır. Oysa ki toplu pazarlık ve neticesindeki toplu iş sözleşmelerinin imzalanabilmesi çalışanların sendikalaşmasını sağlayabilecek cazip koşullardan birisidir. Ayrıca grevlerin 'genel sağlık veya milli güvenliği bozucu nitelikte olması' gibi sebeplerden dolayı 60 gün süreyle geçici olarak yasaklanması ve bu zaman diliminde anlaşma olmaması halinde yeniden grev hakkının tanınması yerine Yüksek Hakem Kurulu'nun vereceği kararların geçerli olması da işverenlere karşı önemli bir caydırıcı güç olan grevin dolaylı yönden yasaklanması olarak değerlendirilmektedir.

Bu çalışmada, Sınıf Teorisini oluşturan sınıf farklılaşması, sendikal eşitsizlikler bağlamında değerlendirilmiştir. Gerek piyasa ekonomisinin gerekse de işverenlerin sendikasızlaştırma çabaları içerisinde oransal olarak oldukça zayıflayan sendikal örgütlenme ile birlikte Türkiye özelinde sendikal hakların kullanımındaki eşitsizlik durumları üzerinde durulmuştur. 


\section{Sendikal Örgütlenme}

Sendikal örgütlenme, çalışanların kendilerini sosyal ve ekonomik tehlikelere karşı korumalarında etkili olmaktadır. Tarihsel süreç içerisinde önceleri Ahilik, Loncalık gibi esnaf birlikleri tarafından yapılan, çalışanların özlük haklarını koruyucu düzenlemeler Sanayi Devrimi ile birlikte sendikalar tarafından yerine getirilmeye başlanmıştır (Saymen, 1948: 82-83). Ekonomik sistem içerisinde çalışanların hak ve özgürlüklerini koruyucu düzenlemelere yer vermesinden dolayı sendikal örgütlenme, demokrasi ile yönetilen toplumların önemli özelliklerinden birisidir (Yorgun, Delen ve Bektaş, 2018: 1918). Örgütlenmede temel mantık ise, bireylerin kendilerinin tek başlarına gerçekleştiremeyecekleri işleri rahatlıkla yapabilecek duruma gelebilmeleridir (Cradden, 2013: 55-56). Çalışanlar, işçi sınıfı olarak kendilerini bir sendika çatısı altında konumlandırdıklarında, toplumsal hiyerarşi içerisinde sınıf bilincinin gereklilikleri çerçevesinde hareket edeceklerdir (Arslan, 2004: 134). Bu da çalışanların sendika çatısı altında kendilerini daha güçlü hissetmelerini sağlayacağından, çalışmalarının karşılığını ücret, statü, saygınlık vb. açıdan almalarına imkân tanıyacaktır. İşçi sınıfının haklarının korunması ve iyileştirilmesinde sendikaların rolü, çalışanların kendilerinin bireysel olarak yaptıklarının toplamından daha fazlasının yapılmasına hizmet etmektir.

Sosyal ve ekonomik haklar arasında yer alan sendikal haklarla, sendikal örgütlenme, toplu pazarlık ve grev hakları bir bütün içinde değerlendirilmektedir. Çünkü bu hakların tümü birbiriyle bağlantılı, biri olmadan diğeri düşünülemeyecek haklardır (Koray, 2005: 239).

Sendikalaşmanın sendika üyesi çalışanlar üzerinde birçok faydası bulunmaktadır. Her şeyden önce çalışanların sendika gibi bir örgüt etrafında bir araya gelmeleri, birbirlerine manevi destek olmalarına ve onları cesaretlendirmelerine imkân tanımaktadır. Bununla birlikte ekonomik olarak da çalışanların bireysel olarak işverenle yapacağı pazarlıktan çok daha fazlasını sendikalar, toplu pazarlık yoluyla elde edebilmektedirler. Toplu pazarlık yapabilen çalışanlar toplu pazarlıklardan yoksun çalışanlara göre daha fazla yan ödeme ve diğer özlük haklarına sahip olmaktadırlar (Miller ve Mulvey, 1992: 125; Cradden, 2013: 57). Sendikaların çalışanları temsil gücü ile birlikte yerel ve ulusal düzeyde alınacak politik kararların çalışanlar lehine sonuçlanabilmesi için de kamuoyu faaliyetleri yapmaları da önemli bir güç olarak değerlendirilebilir (Woos, 1983: 577). Bununla birlikte sendika üyesi olan çalışanların çalışma hayatında kendilerine fayda sağlayacak konular hakkında daha bilinçli oldukları ifade edilebilir (Pontusson, 2013: 819). Sendikaların çalışanları için gerçekleştirdiği toplu pazarlığın, çalışanların kendilerinin yapacağı pazarlıkların toplamından çok daha fazlası olduğu ifade edilebilir. Bireysel pazarlıklarda işveren için caydırıcı güç, kişinin kolaylıkla vazgeçilmeyecek niteliklere sahip olması iken, toplu pazarlıkta bununla birlikte grev gibi işvereni çok daha sarsıcı bir şekilde etkileyebilecek caydırıcı bir güç faktörü söz konusudur. 
Her ne kadar bazı durumlarda özellikle ücretlerin artırılması sürecinde sendikalar piyasa koşulları çerçevesinde monopson olarak değerlendirilseler de öz itibariyle işverenler monopson durumundadır (Piketty, 2015: 94).

Sendikaların kurulması Sanayi Devrimi'nin olumsuz çalışma koşullarına yapılan itiraz ve mücadeleler neticesinde gerçekleşmeye başlamıştır. Sanayileşmenin ilk zamanları liberal ekonomi politikaların etkisi ile çalışanlar için çok olumlu geçmemiştir. Çalışanların ilk örgütlenme tecrübeleri, Fransız İhtilali'nin etkileri ile birlikte hem Fransa'da hem de sanayileşme ile özdeşleşen İngiltere'de yasaklama ile sonuçlandıktan sonra makine kırıcılığı (Ludizm) eylemleri gerçekleştirilmiş ve sonrasında sendikal özgürlükler kazanılmaya başlanmıştır. Sendikal özgürlüklerin iyileştirilmesinde ise Chartizm Hareketi (1838-1848)'nin büyük etkisi olmuş ve 1880'li yıllar ile birlikte sadece vasıflı olan çalışanların değil herkesin sendikaya üye olması neticesinde sendikalaşma gelişmeye ve güç kazanmaya başlamıştır. Sonraları ise her ne kadar 1929 Ekonomik Krizi'nin kısa süreli olumsuz yansımaları gerçekleşmiş olsa da II. Dünya Savaşı sonrasındaki dönemde sendikaların çalışanları lehine önemli kazanımları elde ettikleri y1llar olmuştur. 1980'li yıllar ile birlikte ekonomide neoliberal politikalar uygulanmaya başladığında küreselleşme, post fordist üretim teknikleri vb. uygulamaların da karşılık bulması ile sendikalaşma zayıflamaya başlamıştır (Özatalay, 2016: 139).

Türkiye'de sendikaların oluşumuna kısaca bakıldığında Cumhuriyet Öncesi dönemde sanayileşmenin yeteri düzeyde gerçekleşmemesi ve işçi sınıfının oluşamaması neticesinde 1870 'li yıllarda ilk sendikal örgütlerin ortaya çıtı̆̆ı görülmektedir. II. Meşrutiyet'in ilanı sürecinde Tatil-i Eşgal Kanunu ile birlikte grevlerin ciddi oranda yasaklanması ve sendikalaşmanın kısıtlanması yoluna gidilmiştir. 1938 yılında sendikalaşmayı tamamen yasaklayan uygulamaya 1946 yılında son verilmiş ve 1947 yılında sendikalarla ilgili grev hakkı içermeyen ilk yasal düzenleme olan 5018 sayılı kanun çıkarılmıştır. 1963 yılında da 275 sayılı Toplu İş Sözleşmesi, Grev ve Lokavt Kanunu ile ilk kez grev ile ilgili düzenlemelere yer verilmiştir. 1983 yılında sendikalarla ilgili çıkarılan 2821 ve 2822 sayılı kanunlarda ve yürürlükte olan 6356 sayılı Sendikalar ve Toplu İş Sözleşmesi Kanunu'nda neo-liberal politikaların yansıması görülmektedir (Mahiroğulları, 2005: 7-404; Mahiroğulları, 2020: 171-280 ve Tokol, 2012: 1-347).

\section{Sendikal Örgütlenme ve Eşitsizlikler}

Eşitsizlik, kapitalist toplumların başta gelen ortak özelliklerindendir. Toplumların sosyo-politik yapılarını anlayıp açıklamayı hedefleyen sosyal bilimciler öncelikle, temelini "eşitsizlik" kriterinden alan "iktidar yapısı”" ve "güç ilişkilerini”" inceler. Hemen her toplumda var ola gelen bu eşitsizlikler uzmanlık bilgisi gerektirmeksizin, herkes tarafindan kolaylıkla gözlemlenebilir (Arslan, 2003: 115).

Eşitsizlik, Aydınlanma Çağı'nın bazı filozoflarına göre toplumsal işleyişin doğal bir parçası olarak değerlendirilmektedir. Eşitsizlik doğal ise, tekel, düşük ücret, serbest 
piyasa, serbest ticaret gibi kapitalizm için elzem olan olgular da doğal olarak değerlendirilecektir. Klasik Okul iktisatçıları, yoksulluğun insanı çalışmaya sevk ettiğini söylemişler ve yoksulluk yasaları, asgari ücret gibi düzenlemelere amansız karşı çıkmıştır. Ancak Klasik Okul'dan hemen sonra hem eylemsel hem de düşünsel olarak bu doğallık (Marx tarafından) sorgulanmaya ve bütün insanların iktisadi ve siyasi olarak eşit olduğu dillendirilmeye başlanmıştır (Yıldırım, 2011: 8-9).

Eşitsizlik ve yoksulluk, hem bireyi hem de toplumu etkilemekte, ayrımcılık yaratmakta, sosyal uyumu bozup, siyasi yapıyı şekillendirmektedir. Eşitsizlik ve yoksulluk, son yıllarda artmakta, BM, Dünya Bankası, IMF veya OECD gibi uluslararası örgütlerin gündeminde kilit unsurlar arasında yer almaktadır (Yorgun, 2019: 210; Standing, 2015: 104).

Eşitsizlik olgusundan hareketle, bilim adamları uzun yılların çabalarının bir birikimi ve ürünü olarak, toplumların iktidar yapılarını ve toplumda cereyan eden güç ilişkilerini anlayıp açıklamaya yönelik iki ana teorik yaklaşım ortaya koymuştur. Bunlardan bir tanesi "sınıf teorisi", bir diğeri ise "elit teorisi"dir. Sınıf teorisinde ekonomik eşitsizliklerden yola çıkılır ve sınıf farklılaşması açıklanırken, "sahiplik" ve "kontrol" kavramları kullanılır. Bir yanda mülkiyeti elinde bulunduran kapitalist sınıf, diğer yanda da sermaye ve mülkiyete sahip bulunmayan çalışan sınıfı olmak üzere iki büyük sosyal sınıfın çatışmaları konu edinilmektedir. Elit teorisinde ise daha çok sosyopolitik eşitsizlikler ön planda tutulur (Arslan, 2004: 126-127; Türkdoğan, 2013: 163).

Sanayi Devrimi'ne kadar olan dönemdeki ekonomik ilişkiler ve büyümeye bakıldığında daha durağan bir işleyişin olduğu ve bunun karşılığında da eşitsizliklerin nispeten daha az olduğu söylenebilir (Dickson, 2015: 339). Sanayi Devrimi ile birlikte şekillenen kapitalist üretim ilişkilerinin, çalışma ve emek açısından oluşturduğu en önemli sonuçlardan birisi de emeğin mübadele niteliğine sahip diğer mallar gibi piyasada arz ve talep kurallarına tabi olması, bir diğer ifadeyle, metalaşması olmuştur. Ancak, emeğin sahibinin insan olması onu piyasa kurallarına tabi olan diğer unsurlardan ayıran temel bir özelliktir (Metin ve Özaydın, 2016: 37).

Özellikle küreselleşme ile birlikte uygulanan iktisadi politikalar hem ülkeler arasında hem de ülkeler içinde gruplar arasında keskin farklılaşmaların ortaya çıkmasına ve giderek artmasına sebep olmuştur. Dolayısıyla eşitsizlik günümüzde çözümlenmeyi ve çözülmeyi bekleyen büyük bir sosyal sorundur (Sunar, 2016: 2). Piyasa olarak ifadelendirilen ekonomik işleyiş, sosyal ve siyasal aktörleri dışlayarak hak kavramını anlamsızlaştırmakta, kişisel çıkar dürtüsü temelinde işlemektedir. Kendi kuralları içerisinde işleyen ekonomik yapıda insan hakları ile ilgili hususlarda başarılı olma kaygısı taşımamaktadır. Burada üzerinde durulması gereken husus ise, piyasaya müdahaleden ziyade insan haklarının korunmasının piyasaya bırakılmaması olmalıdır (Buğra, 2005:386-388). 
Gelişmiş ve gelişmekte olan ülkelerde piyasanın kuralsızlaştırılması ve küreselleşme ile birlikte işçi sendikalarının gücünün azaldığı görülmektedir. Gerek refah devleti ile ilgili iyi uygulama örneklerinin yaşanması gerekse de insan hakları, demokrasi gibi kavramlarda yaşanan söylem zenginliğinin, emeğini sunan çalışanların haklarının korunabilmesine katkı sunamayacak şekilde, bu dönemde gerçekleşiyor olması önemli bir tezat olarak düşünülmelidir (Erdut, 2005: 43). Çalışanların sendikalar etrafında yer almaları güçlü olabilmeleri için gerekli bir koşuldur. Emek piyasasındaki artan eşitsizlik, eğretilik ve güvencesizlik sosyal adaletin sağlanacağı beklentisi düşüncesini de zayıflatmaktadır (Erdut, 2007: 81). Sosyal adaletin sağlanabilmesi için çalışanların oluşturduğu örgütlü yapıların 'ne yapmaları gerekliliği ile ilgili sürekli kendilerine tavsiyede bulunulan' mesleki yapı içerisinde değil de işverenlerle, aracılarla ve hükümet temsilcileri ile sürekli pazarlık etmesini sağlayacak örgütsel yapıları oluşturmaları gerekmektedir (Standing, 2015: 276-277). Sendikal örgütlenmeler, her halükarda çalışanlar arasındaki eşitsizliklerin ortadan kaldırılması için çalışmalar yapmaktadır (Piketty, 2015: 89).

Halihazırda işleyen neoliberal ekonomi uygulamaları ile birlikte her ne kadar hala bir tartışma konusu olsa da sosyo-ekonomik hakların da hayata geçirilmesi gerekir. Eğitim ve sağlık hakkı, çalışma hakkı, sendikal örgütlenme hakkı, toplu sözleşme ve grev hakk1 ile birlikte sosyal güvenlik hakk1 sosyo-ekonomik hakların ana gövdesini oluşturmaktadır (Koray, 2005: 81-82). Temel hakların piyasanın insafina bırakılması çalışanlar, başta ücret düşüklügü olmak üzere gelir eşitsizliğinin nedeni olarak değerlendirilebilecek unsurlarla karşılaşacaklardır (Yıldırım, 2011: 73). Gelir dağılımındaki adaletsizlikler neticesinde her ne kadar ücretli bir işte çalışıyor olunsa da çalışan yoksulluğu gibi bir kavramın ortaya çıkmasına, çalışanların kendilerine yeteri kadar kazanamadıkları bir durum oluşturmaktadır (Candaş vd., 2010: 36-37; Öztürk, 2014: 51).

\subsection{OECD Ülkeleri ve Sendikal Örgütlenme}

Dünya'daki çalışanların örgütlenme durumlarını gösteren OECD ülkelerindeki sendikalaşma seviyelerine bakıldığında, her ülkenin sendikalaşma düzeylerinin birbirlerinden farklı olduğu ifade edilebilir. Çalışanların sendikalaşmalarında uluslararası düzeyde önemli bir kazanım olarak değerlendirilen 1948 yılında ILO tarafından kabul edilen 87 nolu 'Sendika Özgürlüğü ve Sendikalaşma Hakkının Korunması Sözleşmesi' ${ }^{1}$ ile 1949 yılında kabul edilen 98 nolu 'Örgütlenme ve Toplu

1 Türkiye'nin 1992 yılında onayladığı 87 nolu ILO Sözleşmesini kabul etmeyen ülkeler: Afganistan, Bahreyn, Brezilya, Brunei Sultanlığı, Çin, Cook Adaları, Gine, Hindistan, İran, Ürdün, Lao Demokratik Halk Cumhuriyeti,Lübnan, Malezya, Marşal Adaları Fas, Nepal, Yeni Zelanda, Umman, Palau, Katar, Kore Cumhuriyeti, Suudi Arabistan, Singapur, Güney Sudan, Sudan, Tayland, Tonga, Tuvalu, Birleşik Arap Emirlikleri, Amerika Birleşik Devletleri, Vietnam (https://www.ilo.org). 
Pazarlık Hakkı Sözleşmesi' ${ }^{2}$ birçok ülke tarafından onaylanmış olsa da sendikalaşma oranları farklılık göstermektedir. $\mathrm{Bu}$ durum emeğin örgütlenmesinde ülkelerin çoğunluğu tarafından kabul edilen ilkesel kararların pratik düzeydeki yansımalarının çalışanların yaşadıkları problemleri ortadan kaldıracak şekilde uygulanmadığını gösteren farklılıklardır.

\section{Tablo 1. OECD Ülkelerinde Sendikalaşma Oranları}

\begin{tabular}{|c|c|c|c|c|c|c|}
\hline No & Country & 2000 & 2005 & 2010 & 2015 & 2018 \\
\hline 1 & Australia & 24,8 & 22,5 & 18,4 & .. & 13,7 \\
\hline 2 & Austria & 36,9 & 33,8 & 28,9 & 27,4 & 26,3 \\
\hline 3 & Belgium & 56,2 & 53,7 & 53,8 & 54,2 & 50,3 \\
\hline 4 & Canada & 31,2 & 30,4 & 30,1 & 29,4 & .. \\
\hline 5 & Chile & 11,8 & 11,7 & 14,6 & 16,1 & .. \\
\hline 6 & $\begin{array}{l}\text { Czech } \\
\text { Republic }\end{array}$ & 27,2 & 19,1 & 16,1 & 12,0 & 11,5 \\
\hline 7 & Denmark & 74,5 & 71,5 & 67,2 & 67,1 & 66,5 \\
\hline 8 & Estonia & 14,0 & 9,4 & 8,1 & 4,7 & 4,3 \\
\hline 9 & Finland & 74,3 & 71,1 & 70,3 & 66,4 & 60,3 \\
\hline 10 & France & 9,5 & 8,6 & 9,0 & 9,0 & 8,8 \\
\hline 11 & Germany & 24,6 & 21,5 & 18,9 & 17,6 & 16,5 \\
\hline 12 & Greece & .. & .. & 22,2 & .. & .. \\
\hline 13 & Hungary & 23,8 & 17,2 & .. & 9,4 & 7,9 \\
\hline 14 & Iceland & 89,4 &.. &.. & 90,0 & 91,8 \\
\hline 15 & Ireland & 36,0 & 32,5 & 33,5 & 25,4 & 24,1 \\
\hline 16 & Israel & 37,7 & .. & .. & .. & .. \\
\hline 17 & Italy & 34,4 & 33,3 & 35,5 & 35,7 & 34,4 \\
\hline 18 & Japan & 21,5 & 18,7 & 18,3 & 17,4 & 17,0 \\
\hline
\end{tabular}

\begin{tabular}{|c|c|c|c|c|c|c|}
\hline No & Country & 2000 & 2005 & 2010 & 2015 & 2018 \\
\hline 19 & Korea & 11,4 & 9,9 & 9,6 & 10,0 &.. \\
\hline 20 & Latvia &.. & .. & 15,0 & 12,6 & 11,9 \\
\hline 21 & Lithuania &.. & .. & 10,1 & 7,9 & 7,1 \\
\hline 22 & Luxembourg & .. & 41,1 & 35,1 & 33,3 & 31,8 \\
\hline 23 & Mexico & 16,7 & .. & 13,8 & 13,1 & 12,0 \\
\hline 24 & & & & & & \\
\hline & $\begin{array}{l}\text { Netherlands } \\
\text { New }\end{array}$ & 22,6 & 22,1 & 19,5 & 17,7 & 16,4 \\
\hline 25 & Zealand & 22,4 & 22,3 & 21,4 & 17,9 & 18,8 \\
\hline 26 & Norway & 52,4 & 50,6 & 50,0 & 49,3 & 49,2 \\
\hline 27 & Poland & 24,7 & 26,0 & 18,3 & .. & .. \\
\hline 28 & Portugal &.. & .. & 19,6 & 16,1 &.. \\
\hline 29 & $\begin{array}{l}\text { Slovak } \\
\text { Republic }\end{array}$ & 32,3 & 22,8 & 15,2 & 11,7 & .. \\
\hline 30 & Slovenia & 44,2 & 37,5 & 29,6 & 20,9 & .. \\
\hline 31 & Spain & 17,4 & 15,9 & 18,3 & 15,2 & 13,6 \\
\hline 32 & Sweden & 86,6 & 81,0 & 70,2 & 67,8 & 64,9 \\
\hline 33 & Switzerland & 20,2 & 19,3 & 17,6 & 15,7 & .. \\
\hline 34 & Turkey & 16,0 & .. &.. & 8,0 & 9,2 \\
\hline 35 & $\begin{array}{l}\text { United } \\
\text { Kingdom }\end{array}$ & 29,7 & 27,0 & 26,8 & 24,2 & 23,4 \\
\hline 36 & $\begin{array}{l}\text { United } \\
\text { States }\end{array}$ & 12,9 & 12,0 & 11,4 & 10,6 & 10,1 \\
\hline
\end{tabular}

Kaynak: https://stats.oecd.org/

2 Türkiye'nin 1952 yılında onayladığı 98 nolu ILO Sözleşmesini kabul etmeyen ülkeler: Afganistan, Bahreyn, Brunei Sultanlığı, Çin, Cook Adaları, Hindistan, İran, Lao Demokratik Halk Cumhuriyeti, Marşal Adaları, Myanmar, Umman, Palau, Katar, Kore Cumhuriyeti, Suudi Arabistan, Tayland, Tonga, Tuvalu, Birleşik Arap Emirlikleri (https://www.ilo.org). 
Zaman içerisinde sendikalaşmanın azaldığının anlaşıldığı yukarıdaki tablodan da görüleceği üzere sendikalaşma oranlarının en yüksek olduğu ülkeler \% 91,8 ile İzlanda, \% 66,5 ile Danimarka ve \% 64,9 ile İsveç olmak üzere Kuzey Avrupa ülkeleridir. Bu durum her ne kadar kuruluş amaçlarından birisi de ulusal düzeyde uygulanan sosyal politikaların yetersizliğini gidermek olan ILO'nun uluslararası platformda emeğin örgütlenmesinde verimli bir şekilde aktif olmadığının da göstergesi olup, uluslararası sendikal mücadele açısından değerlendirildiğinde eşitsizliklerin ortaya çıkmasına engel olamadığını da göstermektedir.

Küreselleşme ile birlikte emeğin de küreselleştiği gerçeğinden hareketle ILO standartlarının gerçekleştirilmesinde yaşanan pratik sorunların küresel çerçeve anlaşmalarda yaşanmaması ve çalışanların emeğinin karşılı̆̆ını alabilmeleri için, ILO'nun özellikle son yıllarda sendikalar ile çokuluslu şirketler arasında gerçekleştirilen ulusaşırı çerçeve anlaşmalarının sonuçlarının pratik yansımaları için daha fazla çalışma yapılması gerekmektedir (Schömann, 2013: 123).

ILO'nun önemli kararlarının alındığı Uluslararası Çalışma Konferansı'nın işleyişine bakıldığı zaman her ne kadar üye ülkeleri temsil etmede çalışanları da temsilen bir üye bulundurma zorunluluğu yer alsa da, karşısında işverenleri temsilen bir üye ve devleti temsilen ise iki üye bulunmaktadır (Nurdoğan, 2018: 84). Bu durum çalışanların özellikle uluslararası düzeyde örgütlenmesinde önemli bir aşama iken günümüz neo-liberal ekonomi politikaları dikkate alındığında endüstri ilişkileri aktörlerinin ILO'daki temsil düzeylerinin çalışanlar aleyhine bir durum oluşturduğunu ifade etmek yanlış olmayacaktır. Temsil açısından kritik bir pozisyonda yer alan devletin her ne kadar çalışanları aleyhine olan kararları almasının çok kolay olmadığ düşünülse de diğer bir aktör olan işverenlere karşı müdahalesi sınırlı kalmaktadır.

\subsection{Türkiye’de İşkolları Sendikalaşma Oranlarındaki Farklılıklar}

Türkiye'de sendikalaşma oranı 2020 yılı Ocak ayı verilerine göre \% 13,84'tür. Aile, Çalışma ve Sosyal Hizmetler Bakanlığı'nın verilerine göre 13.856.801 kayıtlı işgücünün 1.917.886'sı sendika üyesi olarak çalışmaktadır. 6356 sayılı Sendikalar ve Toplu İş Sözleşmesi Kanunu'na göre işçi sendikalarının üye olabileceği 20 işkolu belirlenmiştir. Sendikalaşma oranlarının detaylı bir şekilde yer aldığı aşağıdaki tabloda da görüleceği üzere genel olarak \% 13,84 şeklinde açıklanan sendikalaşma oranı her bir işkolunda benzer ortalamaya sahip bir şekilde gerçekleşmemiştir. 


\section{Tablo 2. Türkiye'de Sendikalaşma Oranı}

\begin{tabular}{|c|c|c|c|c|c|}
\hline $\begin{array}{l}\text { İşkolu } \\
\text { Kodu }\end{array}$ & İşkolu & Toplam İşçi & $\begin{array}{l}\text { Sendika Üye } \\
\text { Sayısı }\end{array}$ & $\begin{array}{l}\text { Kendi } \\
\text { İşkolundaki } \\
\text { Sendikalaşma } \\
\text { Oranı }\end{array}$ & $\begin{array}{l}\text { Genel } \\
\text { Sendikalaşma } \\
\text { Oranı }\end{array}$ \\
\hline 01 & $\begin{array}{l}\text { Avcılık, Balıkçılık, Tarım } \\
\text { ve Ormancılık }\end{array}$ & 139.737 & 28.029 & 20,06 & 1,46 \\
\hline 02 & Gıda Sanayi & 626.346 & 72.138 & 11,52 & 3,76 \\
\hline 03 & Madencilik ve Taş Ocakları & 177.732 & 37.624 & 21,17 & 1,96 \\
\hline 04 & $\begin{array}{l}\text { Petrol, Kimya, Lastik, } \\
\text { Plastik ve İlaç }\end{array}$ & 502.615 & 57.219 & 11,38 & 2,98 \\
\hline 05 & $\begin{array}{l}\text { Dokuma, Hazır Giyim ve } \\
\text { Deri }\end{array}$ & 1.148 .954 & 101.627 & 8,85 & 5,30 \\
\hline 06 & Ağaç ve Kağıt & 233.475 & 19.984 & 8,56 & 1,04 \\
\hline 07 & İletişim & 72.377 & 16.650 & 23,00 & 0,87 \\
\hline 08 & Basın, Yayın ve Gazetecilik & 86.329 & 6.893 & 7,98 & 0,36 \\
\hline 09 & Banka, Finans ve Sigorta & 290.706 & 99.461 & 34,21 & 5,19 \\
\hline 10 & $\begin{array}{l}\text { Ticaret, Büro, Eğitim ve } \\
\text { Güzel Sanatlar }\end{array}$ & 3.811 .060 & 201.119 & 5,28 & 10,49 \\
\hline 11 & Çimento, Toprak ve Cam & 149.896 & 34.905 & 23,29 & 1,82 \\
\hline 12 & Metal & 1.566 .446 & 272.275 & 17,38 & 14,20 \\
\hline 13 & İnşaat & 1.110 .229 & 49.347 & 4,44 & 2,57 \\
\hline 14 & Enerji & 235.206 & 71.607 & 30,44 & 3,73 \\
\hline 15 & Taşımacılık & 824.447 & 86.377 & 10,48 & 4,50 \\
\hline 16 & $\begin{array}{l}\text { Gemi Yapımı ve Deniz } \\
\text { Taşımacilığl, Ardiye ve } \\
\text { Antrepoculuk }\end{array}$ & 186.995 & 17.088 & 9,14 & 0,89 \\
\hline 17 & Sağlık ve Sosyal Hizmetler & 468.669 & 61.384 & 13,10 & 3,20 \\
\hline 18 & $\begin{array}{l}\text { Konaklama ve Eğlence } \\
\text { Hizmetleri }\end{array}$ & 927.146 & 36.651 & 3,95 & 1,91 \\
\hline 19 & Savunma ve Güvenlik & 304.300 & 135.483 & 44,52 & 7,06 \\
\hline 20 & Genel İşler & 994.136 & 512.025 & 51,50 & 26,70 \\
\hline \multicolumn{2}{|c|}{ Toplam İşçi } & 13.856 .801 & 1.917 .886 & --- & 13.84 \\
\hline
\end{tabular}

Kaynak: https://www.ailevecalisma.gov.tr/istatistikler/calisma-hayati-istatistikleri/sendikalistatistikler/isci-sayilari-ve-sendikalarin-uye-sayilari-hakkinda-tebligler/

Sosyal taraflar arasında sosyal diyaloğun gelişme şartlarından biri güçlü organizasyon yapılarıdır. Yani işverenler karşısında işçilerin de güçlü organizasyonlara sahip olmaları gerekir. Bunun temel şartlarından biri bölünmemiş sendikal yapıdır. Türkiye'deki sendikal yapı incelendiğinde bunun çok başlı bir şekilde organize edildiği görülmektedir (Cam, 2013: 149). 
Yukarıdaki tabloda görüldüğü üzere işkolları içerisinde en fazla sendika üyesinin \% 26,70 (512.025 kişi) ile 20 nolu Genel İşler İşsolunda çalışanlardan oluştuğu görülmektedir. Genel İşler olarak ifadelendirilen işkolu içerisinde ağırlıklı olarak yerel yönetimler alanında çalışanlar yer almaktadır. Genel sendikalaşmaya Genel İşler İşkolu'ndan sonra en fazla katkıyı 12 nolu Metal İşkolu \% 14,20 (272.275 kişi) ile, 10 nolu Ticaret, Büro, Eğitim ve Güzel Sanatlar İşkolu \% 10,49 (201.119) oranı ile vermektedir.

İşkollarının kendi içerisindeki sendikalaşma oranları genel sendikalaşmaya sundukları katkı ile doğru orantılı bir şekilde gerçekleşmemiştir. 20 nolu Genel İşler İşkolu'ndaki çalışanların kendi işkolu içerisindeki sendikalaşma oranı \% 51,50 (512.025 kişi) iken, işkolları içerisinde ikinci sırada en fazla sendikalaşma \% 44,52 (135.483 kişi) ile 19 nolu Savunma ve Güvenlik işkolunda, daha sonra ise \% 34,21 (99.461 kişi) ile 9 nolu Bankacılık, Finans ve Sigorta işkolu ile \% 30,44 (71.607 kişi) ile 14 nolu Enerji işkolundaki çalışanlardan oluşmaktadır (https://www.ailevecalisma.gov.tr/media/35790/2020-ocak.pdf).

Genel olarak işkolu sendikacılığının benimsendiği ve 20 işkolunun belirlendiği Türkiye'de, birçok işkolunda \% 1'lerin altında bir sendikalaşma düzeyi var iken, sadece iki işkolu Türkiye'deki ortalama sendikalaşma oranının üzerindedir.

\subsection{Kayıt dışı Çalışanlar ve Sendikalaşma}

Türkiye'de sendikalaşma oranları Aile, Çalışma ve Sosyal Hizmetler Bakanlığı tarafından Ocak ve Temmuz ayları olmak üzere yılda iki defa ilan edilmektedir. Sendika üye sayılarının belirlenmesinde sendikaların Bakanlığa bildirdikleri sayılar dikkate alınmakta olup ihtilaf olması durumunda Sosyal Güvenlik Kurumu'nun verilerinden de yararlanılmaktadır. OECD verilerine bakıldığında ise Türkiye'deki sendikalaşma oranları Bakanlığın ilan etmiş olduğu oranlardan daha aşağı seviyededir.

Sendikalaşma oranları ile ilgili OECD tarafından açıklanan Tablo 1.'e bakıldığı zaman Türkiye'de sendikalaşma oranı 2018 y1lı için \% 9,2, toplam çalışan sayısı 19.523.000 (sendikalı çalışan sayısı: 1.802.000) olarak açıklanmıştır (www.stats.oecd.org). Kayıt dışı çalışmak başta sosyal güvenlik ile ilgili özlük hakları olmak üzere çalışanlara fayda sağlayabilecek birçok sosyal güvencenin kullanılamaması anlamına gelmektedir. Türkiye'de sendikalaşma oranlarının hesaplanmasında da dikkate alınmaması, onların sendika üyesi olarak çalışma hayatında yer al(a)madıklarının göstergesidir. Türkiye'de SGK'nın açıkladığ 1 verilere göre her üç çalışandan biri (2018 yılı \% 33,41) kayıt dışı çalışmaktadır (www.sgk.gov.tr). Bu durum çalışanların birçoğunun sendika içerisinde yer alamaması anlamına da gelmekte olup toplam çalışanların üçte ikisi sendika kurabilmekte, sendikalara üye olabilmekte ve sendikal mücadeleler içerisine girebilmektedir. 
Kayıt dışı çalışmanın yüksek olduğu yerde iş kanunu ve endüstri ilişkileri ile ilgili kapsayıcı düzenlemelerin gerçekleştirilmesinin zorluğundan hareketle sendikacılığın gelişmesi de zor olmaktadır (Karakoyunlu, 2000: 546; Lordoğlu, 2000: 504). Türkiye'deki istatistiki verilerin hesaplanmasında dahi dikkate alınmadıkları için kayıt dışı çalışanların toplu pazarlık gibi sendikalaşmanın sağlayabileceği temel katkılardan, 'üretilen katma değerden hakça pay alma' imkanından mahrum kalmaları söz konusu olmaktadır (Mahiroğulları, 2017: 559).

\subsection{Sendikalaşmanın Sektörel Olarak Farklılık Göstermesi}

Sendikalaşma oranlarının kamu-özel sektör arasındaki dağılımlarına bakıldığında sektörel olarak ciddi farklılıklar olduğu görülmektedir. Kamu görevlilerinin sendikası ile işçilerin sendikalaşma oranları genel olarak karşılaştırıldığında, her ne kadar sendikalaşmada temel haklardan birisi olarak değerlendirilen grev hakkı olmasa da kamu görevlilerinin sendikalaşma düzeylerinin işçilerin sendikalaşma oranlarından daha yüksek olduğu görülmektedir. Türkiye'de kamu görevlisi olarak çalışanların sendikalaşma oranları \% 69 iken, işçi statüsünde çalışanların sendikalaşma oranı ise \% 13,84'tür(https://www.ailevecalisma.gov.tr/tr-tr/istatistikler/calisma-hayati-

istatistikleri/sendikal-istatistikler/kamu-gorevlileri-istatistikleri/). Sendikaların çok büyük bir bölümü yıllardır, daha kolay ve zahmetsiz örgütlenme imkânı sağlayan kamu sektöründe örgütlü bulunmaktadır (Uçkan ve Kağnıcıŏ̆lu, 2009: 54).

Ayrıca sendika üyesi işçilerin bir kısmı da kamu kurumlarında çalışmaktadırlar. Türkiye'de sendikalaşma oranlarının gösterildiği Tablo 2.'ye bakıldığında en yüksek sendikalaşma oranının gerçekleştiği işkolunun 20 nolu Genel İşler olduğu görülmektedir. Hem kendi işkolundaki toplam çalışanlar içerisinde hem de genel sendikalaşma oranı içerisinde Genel İşler'de çalışanların daha yüksek bir sendikalaşma oranına sahip olduğu anlaşılmaktadır. Genel İşler işkolundaki sendikalara bakıldığında bir kamu kuruluşu olan yerel yönetim çalışanlarının ağırlıklı olarak yer aldığı görülmektedir. Sendika üyesi olan 512.025 üyenin 302.911'i Tüm Belediye ve Genel Hizmet İşçileri Sendikası (Genel-İş), 103.747si Türkiye Belediyeler ve Genel Hizmetler İşçileri Sendikası (Belediye-İş) gibi Genel İşler işkolunda üye olan sendikaların \% 79'una karş1lı gelmektedir (https://www.ailevecalisma.gov.tr/media/35790/2020ocak.pdf).

\subsection{Toplu Pazarlık ve Toplu Sözleşme Hakkının Kullanımındaki Farklılıklar}

Toplu pazarlık; işçi sendikası ve işveren ya da işveren sendikası arasında sürdürülen ve işyeri/işletme veya işkolu düzeyinde ücret ve çalışma koşullarını belirlemeye yönelik bir sözleşme ya da iş uyuşmazlığı ile sonuçlanan pazarlık süreci (Önsal, 2017: 503) şeklinde tanımlanmaktadır. Toplu pazarlık aynı zamanda işverenlerin yeni pazarlar, yeni kaynaklar aramak yerine kendilerinden daha alt kesimde olan çalışanların ücretlerinin daha fazla düşürülmemesi, onların tekel oluşturmalarını 
engelleme adına dolaylı yönden işverenler için de olması gereken bir düzenlemedir (Hicks, 1963: 65). Toplu pazarlık, çalışma koşullarının çalışanlar ile işverenler tarafından belirlenmesine katkı sunarak çalışanların sendikaları aracılığıyla çalışma hayatı içerisinde bir aktör olarak yer almasını sağlamaktadır.

\section{Tablo 3. OECD Ülkelerinde Toplu Pazarlık Yapılma Oranları}

\begin{tabular}{|c|c|c|c|c|c|c|c|c|c|c|c|c|c|}
\hline $\begin{array}{l}\mathrm{N} \\
\mathrm{O}\end{array}$ & Country & 2000 & 2005 & 2010 & $\begin{array}{l}201 \\
5\end{array}$ & $\begin{array}{l}201 \\
7\end{array}$ & $\begin{array}{l}\mathrm{N} \\
\mathrm{o}\end{array}$ & Country & 2000 & 2005 & $\begin{array}{l}201 \\
0\end{array}$ & $\begin{array}{l}201 \\
5\end{array}$ & $\begin{array}{l}201 \\
7\end{array}$ \\
\hline 1 & $\begin{array}{l}\text { Australi } \\
\text { a }\end{array}$ & 60,0 & .. & 58,7 & .. & .. & 20 & Latvia & .. & 15,0 & 20,4 & 14,8 & .. \\
\hline 2 & Austria & 98,0 & 98,0 & 98,0 & 98,0 & 98,0 & 21 & Lithuania & .. & .. & 11,1 & 7,1 & .. \\
\hline 3 & Belgium & 96,0 & 96,0 & 96,0 & 96,0 & 96,0 & 22 & $\begin{array}{l}\text { Luxembour } \\
\mathrm{g}\end{array}$ & 60,0 & 58,0 & .. & .. & 59,0 \\
\hline 4 & Canada & 30,4 & 29,9 & 29,1 & 28,4 & 28,1 & 23 & Mexico & 13,2 & .. & 13,6 & .. & .. \\
\hline 5 & Chile & .. & .. & 15,3 & 18,8 & .. & 24 & Netherlands & 81,7 & 86,8 & 89,7 & 79,4 & 77,6 \\
\hline 6 & $\begin{array}{l}\text { Czech } \\
\text { Republi } \\
\text { c }\end{array}$ & 35,3 & 27,0 & 36,9 & 31,6 & .. & 25 & $\begin{array}{l}\text { New } \\
\text { Zealand }\end{array}$ & 20,0 & .. & 15,6 & .. & .. \\
\hline 7 & $\begin{array}{l}\text { Denmar } \\
\mathrm{k}\end{array}$ & 77,7 & 76,7 & 76,5 & 82,0 & .. & 26 & Norway & .. & 74,2 & .. & .. & .. \\
\hline 8 & Estonia & .. & .. & .. & 18,6 & .. & 27 & Poland & 25,0 & .. & 18,6 & 17,2 & .. \\
\hline 9 & Finland & 85,0 &.. & 77,8 & 89,3 & .. & 28 & Portugal & 78,4 & 83,2 & 76,7 & 73,6 & .. \\
\hline 10 & France &.. & .. & 98,0 & .. & .. & 29 & $\begin{array}{l}\text { Slovak } \\
\text { Republic }\end{array}$ & 51,0 & .. & .. & 24,4 & .. \\
\hline 11 & $\begin{array}{l}\text { German } \\
\mathrm{y}\end{array}$ & 67,8 & 64,9 & 59,8 & 56,8 & .. & 30 & Slovenia & $\begin{array}{l}100 \\
0\end{array}$ & $\begin{array}{l}100, \\
0\end{array}$ & 70,0 & 67,5 &.. \\
\hline 12 & Greece & $\begin{array}{l}100, \\
0\end{array}$ & $\begin{array}{l}100 \\
0\end{array}$ & $\begin{array}{l}100 \\
0\end{array}$ & 23,7 & .. & 31 & Spain &. & 85,1 & 87,2 & 86,7 & .. \\
\hline 13 & Hungary & 38,4 & 24,8 & 27,3 & .. & .. & 32 & Sweden & 94,0 & 93,0 & 89,0 & 90,0 & .. \\
\hline 14 & Iceland & 87,0 & .. & .. & 92,0 & .. & 33 & Switzerland & .. & 44,6 & 54,2 & .. & .. \\
\hline 15 & Ireland & 44,2 & 41,7 & .. & .. & .. & 34 & Turkey & 12,6 & 10,3 & 7,0 & 6,7 &.. \\
\hline 16 & Israel & 56,1 & .. & .. & .. & .. & 35 & $\begin{array}{l}\text { United } \\
\text { Kingdom }\end{array}$ & 36,4 & 34,9 & 30,9 & 27,9 & 26,0 \\
\hline 17 & Italy & 80,0 & 80,0 & 80,0 & .. & .. & 36 & $\begin{array}{l}\text { United } \\
\text { States }\end{array}$ & 14,2 & 13,1 & 12,6 & 11,8 & 11,6 \\
\hline 18 & Japan & 21,1 & 19,0 & 17,6 & 16,8 & 16,5 & 37 & $\begin{array}{l}\text { OECD } \\
\text { Total }\end{array}$ & 37,5 & 36,1 & 35,0 & 32,7 & 32,4 \\
\hline 19 & Korea & 15,2 & 13,1 & 12,7 & 13,2 & .. & & & & & & & \\
\hline
\end{tabular}

Kaynak: https://stats.oecd.org/

Yukarıdaki tabloda OECD ülkelerinde çalışanlardan toplu pazarlık uygulamasından yararlananların oranları yer almaktadır. Toplu pazarlık, örgütlü hareket etmenin bir yansıması olup çalışanlar lehine olumlu sonuçlar doğurmaktadır. Ülkelere bakıldığında toplu pazarlık'tan yararlanma oranları ile sendikalaşma oranları arasında bir benzerlik durumu söz konusu olmakla birlikte bu durumun Türkiye için geçerli 
olmadığı ifade edilebilir. OECD'nin Türkiye için açıklamış olduğu sendikalaşma oranı (2018 yılı) \% 9,2 iken toplu pazarlıklardan yararlananların oranı ise \% 6,7 şeklindedir. $\mathrm{Bu}$ veriler sendika üyesi olan her çalışanın toplu pazarlık uygulamalarından yararlanamadığını göstermektedir.

\section{Tablo 4. Türkiye’de TíS Kapsamındaki Çalışan Sayısı}

\begin{tabular}{|c|c|c|c|c|}
\hline Yil & Sektör & $\begin{array}{l}\text { Toplu İş } \\
\text { Sözleşmesi Sayısı }\end{array}$ & $\begin{array}{l}\text { Kapsadığı } \\
\text { İşçi Sayısı }\end{array}$ & $\begin{array}{l}\text { TíS Kapsamındaki } \\
\text { Toplam Çalışan Sayısı }\end{array}$ \\
\hline \multirow{2}{*}{2010} & Kamu & 1.219 & 166.294 & \multirow{2}{*}{338.671} \\
\hline & Özel & 443 & 172.377 & \\
\hline \multirow{2}{*}{2011} & Kamu & 1.313 & 194.322 & \multirow{2}{*}{502.931} \\
\hline & Özel & 821 & 308.609 & \\
\hline \multirow{2}{*}{2012} & Kamu & 1.172 & 100.416 & \multirow{2}{*}{227.672} \\
\hline & Özel & 331 & 127.256 & \\
\hline \multirow{2}{*}{2013} & Kamu & 1.808 & 228.116 & \multirow{2}{*}{661.929} \\
\hline & Özel & 838 & 433.813 & \\
\hline \multirow{2}{*}{2014} & Kamu & 1.167 & 105.577 & \multirow{2}{*}{369.423} \\
\hline & Özel & 514 & 263.846 & \\
\hline \multirow{2}{*}{2015} & Kamu & 881 & 240.278 & \multirow{2}{*}{660.554} \\
\hline & Özel & 756 & 420.276 & \\
\hline \multirow{2}{*}{2016} & Kamu & 788 & 60.552 & \multirow{2}{*}{482.237} \\
\hline & Özel & 1.937 & 421.685 & \\
\hline \multirow{2}{*}{2017} & Kamu & 833 & 235.720 & \multirow{2}{*}{800.288} \\
\hline & Özel & 3.639 & 564.568 & \\
\hline
\end{tabular}

Kaynak: https://www.ailevecalisma.gov.tr/media/3394/tis-2017.pdf

Toplu pazarlık süreci, sosyal diyalog için önemli bir mekanizmadır. Toplu pazarlık görüşmeleri neticesinde imzalanan toplu iş sözleşmesi metni işveren ile çalışanlar arasındaki sosyal diyalogun en somut sonucudur (Cam, 2013: 152). Hak ve görevlerin tanımlanıp değiştirilmesi toplu sözleşme sürecinde gerçekleşir ve iş sağlayan kurumla işçi temsilcileri arasında anlaşmaya tabidir (Cradden, 2013: 57). Çalışma hayatında oluşmuş olan her bir Toplu İş Sözleşmesi (TISS) sendikalaşmanın gücünü de göstermektedir. Sendikalaşma oranlarını göstermesi açısından da önemli bir veri olarak değerlendirilebilir. Yukarıdaki tablodaki verilerden hareketle her yıl farklı sayıda TíS imzalandığı için ortalamasına bakıldığında yıllık yaklaşık 500.000 çalışanın TİS’ten yararlandığı ortaya çıkmaktadır. Oysa ki Tablo 2'de sendikalı çalışan sayısının 1.917.886 olduğu düşünüldüğünde sendikalı çalışanların neredeyse yaklaşık olarak sadece 1/4'ünün sendikaların çalışanlara önemli bir katkısı olan TİS hükümlerinden yararlandığı ortaya çıkmaktadır. 
6356 sayılı Sendikalar ve Toplu İş Sözleşmesi Kanunu'nun 41. Maddesinde toplu iş sözleşmesi yapmaya yetkili sendika şu şekilde belirlenmiştir. "Kurulu bulunduğu işkolunda çalışan işçilerin en az yüzde birinin üyesi bulunması şartıyla işçi sendikası, toplu iş sözleşmesi kapsamına girecek işyerinde başvuru tarihinde çalışan işçilerin yarıdan fazlasının, işletmede ise yüzde kırkının kendi üyesi bulunması kaydıyla bu işyeri veya işletme için toplu iş sözleşmesi yapmaya yetkilidir" (07.11.2012 tarih ve 6356 sayılı Sendikalar ve Toplu İş Sözleşmesi Kanunu). Sendika üyesi çalışanlar için önemli kazanımlardan birisi olan toplu pazarlık aşamasına her sendikanın katılamamasında kurulu bulunduğu işkolundaki çalışanların en az \% 1'inin sendika üyesi olma koşulunun olmasının da etkili olduğu ifade edilebilir. $\mathrm{Bu}$ ve buna benzer işkolu ve işyeri barajları gibi şartlar ile birlikte önemli bir sosyal diyalog mekanizması olan toplu pazarlıkların zayıflatılması ve sendikasızlaştırma durumu ortaya çıkmaktadır (Cam, 2013: 151).

Toplu pazarlık görüşmelerinde belli bir baraj şartının olmasının sendikaların daha güçlü olabileceği ya da baraj şartı olmadığı zaman sendikaların 'sarı sendika' olma ihtimalleri tartışmaları (Cam, 2013: 154-160) yaşanıyor olsa da baraj şartının sağlanamadığ 1 durumlarda toplu sözleşmelerin imzalanamamasının çalışanlar için çok talep edilmeyen bir durum olduğu açıktır.

\subsection{Grev Hakkının Kullanımında Yaşanan Eşitsizlik}

Toplu pazarlık süreci her zaman için yapılan görüşmeler ve neticesindeki anlaşmalar ile toplu iş sözleşmesinin imzalanması şeklinde sonuçlanmayabilmektedir. Toplu pazarlık ya da toplu iş sözleşmesi hükümlerinin uygulanması aşamasındaki anlaşmazlıklar neticesinde çalışanlar işvereni kararından vazgeçirebilmek için grev gibi caydırıcı bir eylem içerisine girebilmektedir (Hicks, 1963: 146). Türkiye'de çıkar grevi bir 'hak' olarak düzenlenmiş olup, toplu pazarlık aşamasında anlaşmazlık olması durumunda greve gidilebileceği yasal olarak düzenlenmiştir. Toplu pazarlık sürecinde elde edilen kazanımların uygulanmamasında ise greve gitmek yasal olarak düzenlenmediği için mahkemeler yoluyla hakların aranması tercih edilmişstir.

Grev hakkının kullanımı ile ilgili çalışanların aleyhine bir durum da grevin bazı hallerde Cumhurbaşkanlığı tarafından 'genel sağlık ve milli güvenliğe tehdit olarak' değerlendirildiği sürelerde 60 gün süreyle ertelenebilmesidir ki bu durum aslında bir ertelemeden daha çok dolaylı yönden grevin yasaklanmasıdır.

Yürürlükte olan 6356 sayılı Sendikalar ve Toplu İş Sözleşmesi Kanunu'nun 63. Maddesinde grev erteleme süresinin sonunda anlaşma sağlanamamışsa altı iş günü içerisinde taraflardan birinin başvurusu üzerine Yüksek Hakem Kurulu tarafindan anlaşmazlık çözüme kavuşturulmakta ve alınan karar kesin hükmündedir. Türkiye'nin ILO tarafından eleştirilmesine ve problem yaşamasına da neden olan bu durum grev hakkının dolaylı yönden yasaklanması anlamına gelmektedir (Caniklioğlu, 2013: 313). ILO normlarına uygunluk açısından Anayasanın 54. Maddesindeki "grev ve lokavtın 
yasaklandığı hallerde veya ertelendiği durumlarda ertelemenin sonucunda anlaşmazlık Yüksek Hakem Kurulunca çözülür” hükmünün değiştirilmesi ILO normlarına uygun hareket edilmesi gerekmektedir (Dereli, 2013: 61-62).

\section{Sonuç ve Değerlendirme}

Çalışanların istihdam biçimlerinin tipik istihdam modellerinden atipik istihdam modellerine doğru değişmeye başlaması ve imalat sektörü gibi çalışanların bir araya gelmelerini kolaylaştırıcı çalışma koşullarından hizmet sektörüne geçilmesi ile yaşanan sınıf tartışmaları (Yanıklar, 2016: 29-44; Clark ve Lipset, 2015: 287-294) ile birlikte unutulmaması gereken hususlardan bir tanesi 'çalışma'nın kendisinin çalışma biçimleri ve sektörlerinin değişmesinin yanında, toplumsal hayatta yer alanların \% 80 gibi büyük bir çoğunluğunun başkalarına sundukları emeklerinin karşılığını almak üzere bağımlı statüler altında çalışmakta oldukları ve nitelik olarak kendilerini ne kadar geliştirmiş olurlarsa olsunlar sendika gibi mesleki dayanışmayı sağlayabilecek örgütlü yapılara ihtiyaç duymakta oldukları gerçeğinin değişmemesidir.

Sendikaların gücünün zayıflatılmaya çalışılması piyasa içerisindeki faaliyetlerinin zarar görmesinden dolayı toplumsal ve politik yaşamın kalitesi de olumsuz etkilenmektedir (Yorgun, 2019: 213). Bu nedenle çalışanların örgütlü hareket etmesinin piyasanın işleyişini bozduğu ve tekelleşme karşıtı temellere dayalı olarak engellenmesi gerektiği şeklindeki neoliberal tuzak politikalarından vazgeçilmesi gerekmektedir (Standing, 2015: 278).

Sendikal örgütlenme, işçi sınıfının doğuşu ile birlikte çalışanların kolektif hareket etmesi ve bu yönde bilinç geliştirebilmeleri için önemli bir araç olmuştur. Her ne kadar toplumsal hayatta yer alanların büyük çoğunluğunun başkalarının emri altında iş yapmak zorunda kalan çalışanlardan oluştuğu düşünülse de, birlikte hareket edilmediğinde onların yaşadıkları hak kayıpları, eşitsizlikler ve bunların türevi olarak değerlendirilebilecek sorunlar azalmamakta hatta artarak devam etmektedir. Çalışanlarla ilgili problemlerin artarak devam ettiği günümüz çalışma hayatına bakıldığında sendikalaşma oranlarının da giderek azaldığı görülmektedir. Endüstri ilişkilerinde önemli bir aktör olan sendikalar, kapitalist sistem içerisindeki işleyişten daha büyük pasta kapma kaygısı taşımadan (Standing, 2015: 277-278) çalışanların sadece geçimlerini sağlamak için çalışmak zorunda olmalarının karşılığında emeklerinin sömürülmesine müsaade etmemelidir.

Sanayileşmenin ilk dönemlerinde uzun ve ağır çalışma saatleri, kötü çalışma koşulları vb. gibi olumsuz özellikler sendikasız çalışanlarla birlikte düşünüldüğünde örgütlü hareket etmenin önemi daha iyi anlaşılacaktır. Özellikle liberal ekonomik anlayış çerçevesinde gerçekleşen ilk sanayileşme tecrübelerinde çalışanların emeklerinin karşılığını almak yerine emeklerinin sömürüldüğü birçok olumsuz olay yaşanmıştır. İşçi sınıfının oluşmaya başladığı ilk dönemler dikkatli bir şekilde değerlendirildiğinde kavramsal olarak 'sendika' ifadesi kullanılsın ya da kullanılmasın 
örgütlü hareket etmenin çalışanlar için sağladığı yararlar daha farklı şekilde anlaşılmış olacaktır.

Endüstri ilişkilerinde sendikalarla birlikte işverenler ve devlet aktör olarak yer almaktadır. Devlet, endüstri ilişkilerinde piyasanın işleyişini sağlamak şeklinde değerlendirilebilecek düzenleyici rolünde sorumluluk sahibi iken bir diğer görevi de demokratik toplumların temel göstergelerinden birisi olan seçim ile hükümetleri iş başına getiren vatandaşları olan çalışanların özlük haklarının iyileştirilmesi için de kaygı taşıması, çaba sarf etmesi gerekmektedir. Bu süreçte devlet, sendikal örgütlenme gibi çalışanların bireysel olarak pazarlık güçlerinin zayıf olduğu bir ekonomik sistem içerisinde, kendilerini savunabilecekleri yapısal mekanizmalara ihtiyaç duyulabileceği gerçeğinden hareketle gerekli yasal düzenlemeleri yapmalı, çalışanları piyasanın işleyişininin insafına bırakmamalıdır.

Kurumsal olarak her bir aktör ya da kurumlarının işleyişi ile ilgili gerekli görev tanımlarının yer aldığı endüstri ilişkileri sistemi içerisinde, çalışanların örgütlü hareket edememelerinden dolayı yaşadıkları eşitsizliklerin ortadan kaldırılması ve çalışma koşullarının iyileştirilmesinin kişi ya da kurumların iyi niyetli yaklaşımları çerçevesinden çıkarılıp temel bir 'hak' olarak değerlendirilmesi gerekmektedir.

\section{Kaynakça}

07.11.2012 tarih ve 6356 sayılı Sendikalar ve Toplu İş Sözleşmesi Kanunu.

Arslan, D. A. (2003). Eşitsizliğin Teorik Temelleri: Elit Teorisi, Kocaeli Üniversitesi Sosyal Bilimler Enstitüsü Dergisi, 2, 115-135.

Arslan, D.A. (2004). Temel Sorunları ve Açılımları ile Sınıf Teorisi, Sınıf Bilinci ve Orta Sınıflar, Kocaeli Üniversitesi Sosyal Bilimler Enstitüsü Dergisi, 2, 126-143.

Buğra, A. (2005). İktisatçılar ve İnsanlar. 5. Baskı, İstanbul: İletişim Yayınları.

Cam, E. (2013). İsyyerinde Sosyal Diyalog ve Demokrasi. Ankara: T.C. Çalışma ve Sosyal Güvenlik Bakanlığı, Çalışma ve Sosyal Güvenlik Eğitim ve Araştırma Merkezi Yayınları No: 40.

Candaş, A., Buğra, A. Yılmaz, V., Günseli, S. ve Çakar, B.Y. (2010). Türkiye'de Eşitsizlikler: Kalıcı Eşitsizliklere Genel Bir Bakış, İstanbul: Boğaziçi Üniversitesi Sosyal Politika Forumu.

Caniklioğlu, N. (2013). 6356 Sayılı Kanuna Göre Grev Yasakları ve Grevin Ertelenmesi, Çalışma ve Toplum, 2013 (4), 289-316. 
Clark, T. N. ve Seymour, M.L. (2015). Toplumsal Sinıflar Ölüyor mu?, Editörler: Giddens, A., Sosyoloji. (ss. 287-294), 5. Bask1. İstanbul: Say Yay.

Cradden, C. (2013). Bugünü Değiştirmek İçin Geçmişi Anlamak: Sosyal Uzlaşma, Kurumsal Toplum Kuramı ve Endüstriyel İlişkilerin Geleceği, Editörler: Serrano, M., Edlira, X. ve Fichter, M., Sendikalar ve Küresel Kriz, (ss. 47-59), Ankara: Efil Yay.

Dereli, T. (2013). 6356 Sayılı Yeni Sendikalar ve Toplu İş Sözleşmesi Kanunu: Genel Bir Değerlendirme, Çalışma ve Toplum, 2013 (1), 41-64.

Dickson, M. (2015). Küresel Eşitsizlik, Editörler: Giddens, A., Sosyoloji (ss. 339-340), 5. Bask1. İstanbul: Say Yay.

Erdut, T. (2005). İşgücü Piyasasında Enformelleşme ve Kadın İşgücü, Çalışma ve Toplum, 3, 11-49.

Erdut, Z. (2007). Enformel İstihdamın Ekonomik, Sosyal ve Siyasal Etkileri, Çalışma ve Toplum, 1, 53-82.

Hicks, J.R. (1963). The Theory of Wages. 2. Bask1. London: Palgrave Macmillan.

https://stats.oecd.org/ (Erişim Tarihi: 20.05.2020)

www.sgk.gov.tr (Erişim Tarihi: 10.05.2020)

https://www.ilo.org/ (Erişim Tarihi: 12.05.2020)

https://www.ailevecalisma.gov.tr/media/3394/tis-2017_.pdf (Erişim Tarihi: 14.05.2020)

https://www.ailevecalisma.gov.tr/media/35790/2020-ocak.pdf (Erişim Tarihi: 17.05.2020)

https://www.ailevecalisma.gov.tr/tr-tr/istatistikler/calisma-hayati-istatistikleri/sendikalistatistikler/kamu-gorevlileri-istatistikleri/ (Erişim Tarihi: 20.05.2020)

Karakoyunlu, E. (2000). “2000’li Yıllarda Çalışma Yaşamında Beklentiler”, Prof. Dr. Nusret Ekin’ Armă̆an, 543-551.

Koray, M. (2005). Sosyal Politika. 2. Baskı. Ankara: İmge Kitabevi.

Lordoğlu, K. (2000). "Yeni Yüzyılda Sendikasız Bir Sendikacılık Olasılığı Üzerine Tartışma...", Prof. Dr. Nusret Ekin' Armă̆an, s. 501-509. 
Mahiroğulları, A. (2005). Cumhuriyetten Günümüze Türkiye'de İşçi Sendikacılı̆̆ı. İstanbul: Kitabevi Yay.

Mahiroğulları, A. (2020). Dünya'da ve Türkiye'de Sendikacıllk. 4. Bask1. Bursa: Ekin Yay.

Mahiroğulları, A. (2017). Türkiye'de Kayıtdışı İstihdam ve Önlemeye Yönelik Stratejiler, Süleyman Demirel Üniversitesi İktisadi ve İdari Bilimler Fakültesi Dergisi, 22 (2), 547-565.

Metin, B. ve Özaydın, M.M. (2016). Çalışma ve Refah. 2. Baskı. Ankara: Gazi Kitabevi.

Miller, P. ve Mulvey, C. (1992). Trade Unions, Collective Voice and Fringe Benefits, Economic Record, 68 (2), 125-141.

Nurdoğan, A. K. (2018). Uluslararası Çalışma Örgütünün (UÇÖ-ILO) Yüzüncü Yı1 Dönümü ve Türkiye İlişkileri, Bitlis Eren Üniversitesi Akademik İzdüşüm Dergisi, 3 (4), 78-95.

Önsal N. (2017). Endüstri İlişkileri Sözlüğü. 2. Bask1. Ankara: Türk Metal Sendikası Araştırma ve Eğitim Merkezi Yayınları, No: 12.

Özatalay, K. C. (2016). Neoliberalleşen Türkiye'de İşçi Sınıfının Parçalanması, Editörler: Sunar, L. Türkiye'de Toplumsal Tabakalaşma ve Eşitsizlik, (ss. 139161), İstanbul: Matbu Yayınları.

Öztürk, Ş. (2014), Sosyal Korumada Yeni Sosyal Risk Yaklaşımı, Sosyal Siyaset Konferanslart Dergisi, Say1: 66-67, 43-74.

Piketty, T. (2015). The Economics of Inequality (Çev. Arthur Goldhammer, 6. Bask1), London: The Belknap Press of Harvard University Press.

Pontusson, J. (2013). Unionization, Inequality and Redistribution, British Journal of Industrial Relations, 51 (4), 797-825.

Saymen, F. H. (1948). Türk İşçi Sendikalarının Karakterleri, Sosyal Siyaset Konferanslarl Dergisi, 1, 82-105.

Schömann, I. (2013). Ulusaşırı Çerçeve Anlaşmaları: Kurumsal Yönetişimi Etkileyen Yeni Pazarlık Araçları, Editörler: Serrano, M., Edlira, X. ve Fichter, M., Sendikalar ve Küresel Kriz, (ss. 123-136), Ankara: Efil Yay. 
Standing, G. (2015). Prekarya: Yeni Tehlikeli Sınıf. 3. Baskı. İstanbul: İletişim Yay.

Sunar, L. (2016). Türkiye'de Toplumsal Tabakalaşma ve Eşitsizlik. İsanbul: Matbu Yay.

Tokol, A. (2012). Türk Endüstri İlişkileri Sistemi. 3. Baskı. Bursa: Dora Yay.

Türkdoğan, O. (2013). Sosyal Hareketlerin Sosyolojisi. İstanbul: Bilge, Kültür, Sanat Yay.

Uçkan, B. ve Kağnıcıoğlu, D. (2009). İşçilerin Sendikalara İlişkin Alg1 ve Tutumları, Çalışma ve Toplum, 3, 35-56.

Uslu, A. (2014). Avrupa'da Erken Dönem Sosyalist Teori ve İşçi Hareketleri (18301840), Akademik Incelemeler Dergisi, 9 (1), 1-24.

Woos, P.B. (1983). Union Organizing: Costs and Benefits, ILR Review, 36 (4), 576-591.

Yanıklar, C. (2016). Sınıfın Sonu mu? Sınıf Tartışmalarının Gidişatı, Editörler: Sunar, L. Türkiye'de Toplumsal Tabakalaşma ve Eşitsizlik, (ss. 29-44), İstanbul: Matbu Yayınları.

Yıldırım, C. (2011). Neoliberal İktisat Politikalarının Türkiye'de Orta Sınıfa Etkisi, Abant İzzet Baysal Üniversitesi, Sosyal Bilimler Enstitüsü, İktisat Anabilim Dalı, Yayınlanmamış Doktora Tezi.

Yorgun, S. (2019). Ekonomik Politikalar ve Endüstri İişkilerinin Geleceği. İstanbul: Beta Yay.

Yorgun, S., Delen, M., ve Bektaş, H. (2018). 1963-1994 Yılları Arasında Türkiye'de Gerçekleşen Grevleri Etkileyen Faktörlere İlişkin Ekonometrik Bir Model Önerisi, Çalışma ve Toplum, 4, 1903-1920. 